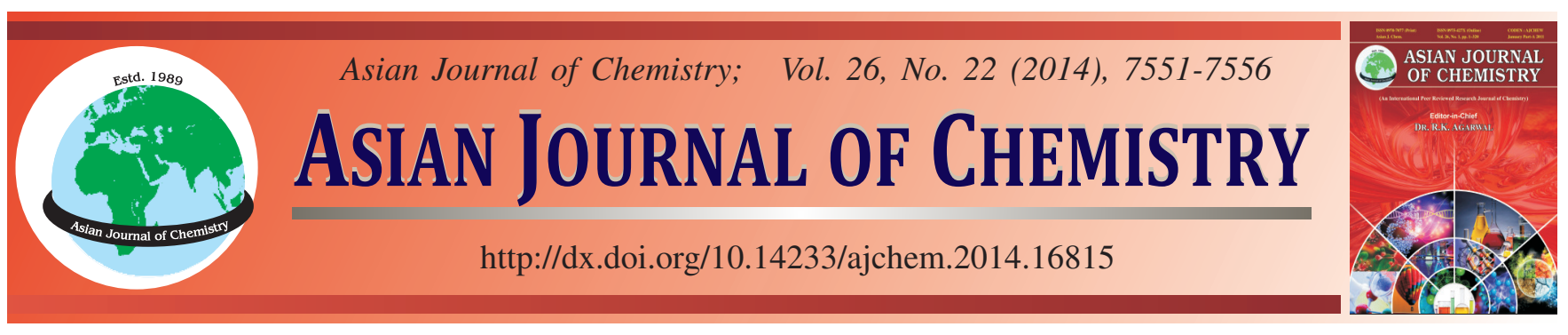

\title{
Development and Statistical Correlation of Spectrophotometric Methods for Atazanavir Sulfate with Sulphonepthalein Dyes
}

\author{
Anindita Behera ${ }^{1, *}$, Dannana G. Sankar ${ }^{2}$, Swapan K. Moitra $^{1}$ and Sudam C. Si ${ }^{1}$
}

\begin{abstract}
${ }^{1}$ School of Pharmaceutical Sciences, Siksha 'O' Anusandhan University, Bharatpur, Ghatikia, Bhubaneswar-751 003, India
${ }^{2}$ Pharmaceutical Analysis and Quality Assurance Division, College of Pharmaceutical Sciences, Andhra University, Visakhapatnam-530 003, India
\end{abstract}

*Corresponding author: E-mail: anindita02@gmail.com

\begin{abstract}
Two simple, extraction free spectrophotometric methods are proposed for analysis of protease inhibitor, i.e., atazanavir sulfate. The methods are based on interaction of the drug with $0.1 \%$ chloroformic solutions of acidic sulphonepthalein dyes to form stable yellow coloured ion pair complexes. Two dyes used are bromophenol blue and bromothymol blue. The yellow chromogens are stable and show absorption maxima at 421.9 and $419.4 \mathrm{~nm}$ with bromophenol blue and bromothymol blue, respectively. The two chromogens follow the linearity in the range of 5-30 and $10-30 \mu \mathrm{g} / \mathrm{mL}$ for bromophenol blue and bromothymol blue respectively. Both methods are validated according to ICH guidelines and statistically compared.
\end{abstract}

Keywords: Atazanavir sulfate, Bromophenol blue, Bromothymol blue, Two way ANOVA, Student's $t$-test.

\section{INTRODUCTION}

Atazanavir sulfate (ATV) (3S,8S,9S,12S)-3,12-bis(1,1dimethylethyl)-8-hydroxy-4,11-dioxo-9-(phenylmethyl)-6[[4-(2-pyridinyl)phenyl]methyl]-2,5,6,10,13-pent-aazatetradecane dioic acid dimethyl ester (Fig. 1), an azapeptide is the $7^{\text {th }}$ protease inhibitor used in the treatment of human immunodeficiency virus (HIV) Type II infection ${ }^{1}$. Atazanavir sulfate is official in IP $2010^{2}$. Atazanavir sulfate is reported as poorly water soluble and a known substrate for both hepatic metabolizing enzyme cytochrome 450 (CYP3A) and intestinal drug efflux pump, P-glycoprotein (Pgp) so have low oral bioavailability ${ }^{3}$. In literature several methods of analysis are reported for determination of atazanavir sulfate in blood plasma, biological cells and cerebrospinal fluid by HPLC ${ }^{4-25}$. Stress degradation studies which were reported, analyzed by HPLC and ultraviolet-spectrophotometry ${ }^{26,27}$. The authors have reported spectrophotometric methods ${ }^{28}$ and HPLC method ${ }^{29}$ in pharmaceutical dosage form. The present work is developed to simplify the extractive spectrophotometric methods using two sulphonepthalein dyes, i.e. brormophenol blue and bromothymol blue.

\section{EXPERIMENTAL}

Reference standard and raw material of atazanavir sulfate were procured from Matrix Laboratories (Hyderabad, India) as gift sample. Solvents used like chloroform, bromophenol blue (BPB) bromothymol blue (BTB) were of analytical grade. Two brands of capsules Atavir 300 (Cipla) and Atazor 200 (Emcure) were purchased from local market.

Preparation of standard solution of atazanavir sulfate: A stock solution of atazanavir sulfate of concentration 100 $\mu \mathrm{g} / \mathrm{mL}$ was prepared by dissolving $10 \mathrm{mg}$ of atazanavir sulfate in $100 \mathrm{~mL}$ of chloroform. Serial dilutions were prepared by taking the aliquots of stock solution each in $10 \mathrm{~mL}$ volumetric flasks and diluting with chloroform.

Preparation of reagent solutions: $0.1 \% \mathrm{w} / \mathrm{v}$ chloroformic solution of bromophenol blue was prepared by dissolving $10 \mathrm{mg}$ of bromophenol blue in $10 \mathrm{~mL}$ of chloroform. $0.1 \%$ chloroformic solution of bromothymol blue was prepared by dissolving $10 \mathrm{mg}$ of bromothymol blue in $10 \mathrm{~mL}$ of chloroform.

Procedure for bromophenol blue: Aliquots $0.5-3.0 \mathrm{~mL}$ of standard atazanavir sulfate was transferred to a series of 10 $\mathrm{mL}$ volumetric flask. To that $2 \mathrm{~mL}$ of $0.1 \%$ chloroformic bromophenol blue was added and kept aside for development of a yellowish chromogen. After 5 min the volume was made up to the mark with chloroform. The resulting solution was scanned against the blank from $380-780 \mathrm{~nm}$ for determination of $\lambda_{\max }$.

Procedure for bromothymol blue: Aliquots 1-3 $\mathrm{mL}$ of standard atazanavir sulfate was transferred to a series of 10 $\mathrm{mL}$ volumetric flask. To that $1 \mathrm{~mL}$ of $0.1 \%$ chloroformic bromothymol blue was added and kept aside for development of a yellowish orange chromogen. After $5 \mathrm{~min}$ the volume 
<smiles>COC(=O)NC(C(=O)NN(Cc1ccc(-c2ccccn2)cc1)C[C@H](O)[C@H](Cc1ccccc1)NC(=O)[C@@H](NC(=O)OO)C(C)(O)O)C(C)(C)O</smiles>

Fig. 1. Chemical structure of atazanavir sulfate (ATV)

was made up to the mark with chloroform. The resulting solution was scanned against the blank from 380-780 nm for determination of $\lambda_{\max }$.

Procedure for sample: Capsules of atazanavir sulfate were purchased from the local market. Contents of capsules were taken out and weighed. Equivalent amount of atazanavir sulfate was calculated and dissolved in chloroform to prepare the solution of $100 \mu \mathrm{g} / \mathrm{mL}$. The sample was treated in the same way with bromophenol blue and bromothymol blue respectively and analyzed at $\lambda_{\max }$.

Validation: Both the methods were validated as per ICH guidelines ${ }^{30}$. The methods are validated in terms of accuracy and precision, limit of detection (LOD) and limit of quantitation (LOQ), specificity and selectivity.

Statistical analysis: To correlate the difference between the two developed methods of spectrophotometry, six different samples were taken from two different brands and quantification was done simultaneously. To test difference between the proposed spectrophotometric methods statistical tests were performed for the level of confidence $95 \%(\mathrm{P}=0.05)$. Two way ANOVA and student's t-test were applied to test the significant difference between both the methods.

\section{RESULTS AND DISCUSSION}

In method A, the drug was allowed to react with bromophenol blue and in method $\mathbf{B}$, the drug was reacted with bromothymol blue in neutral medium. As compared to the reported spectrophotometric method by Behera et al. ${ }^{28}$, the present methods are equally significant from the point of validation parameters and the present work demonstrates the simplified extraction free, ion complexation estimation by spectrophotometric method. The methods are easier than the conventional methods of ion complex estimation by extraction in suitable buffer system. The difficulties in choice of suitable buffer system, preparation and maintenance of buffer system and extraction in suitable organic solvent are overcome by the proposed methods. Statistical correlation of the two methods signifies that there is no significant difference between two developed methods.

Optical characteristics: The absorption spectra of yellowish coloured chromogen of atazanavir sulfate and bromophenol blue had $\lambda_{\max }$ at $421.9 \mathrm{~nm}$ and the yellowish orange product of atazanavir sulfate and bromothymol blue had $\lambda_{\max }$ at 419.4 nm, respectively. The absorption spectra are shown in Figs. 2 and 3. The wavelengths were used for the validation of the methods. The linearity for method A was found at $5-30 \mu \mathrm{g} / \mathrm{mL}$ and for method B at $10-30 \mu \mathrm{g} / \mathrm{mL}$ respectively. The different optical parameters are listed in Table-1.

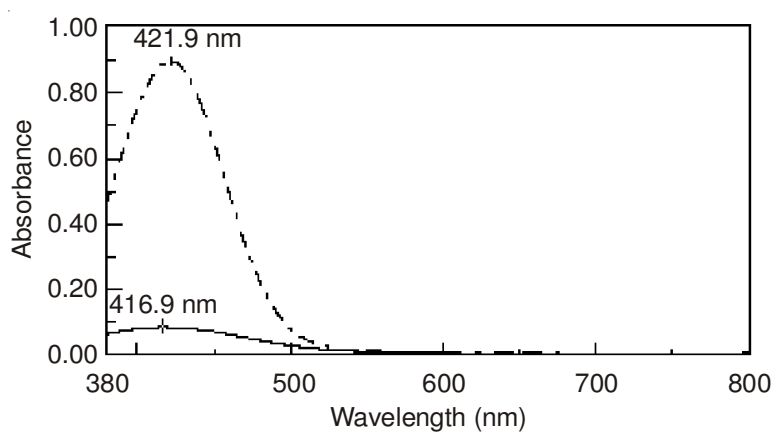

Fig. 2. Absorption spectra of atazanavir sulfate-bromophenol blue (ATV-BPB) chromogen having $\lambda_{\max }$ at $421.9 \mathrm{~nm}$

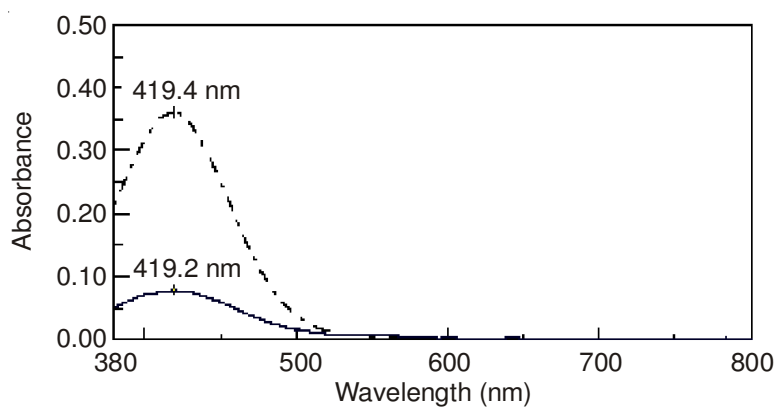

Fig. 3. Absorption spectra of atazanavir sulfate-bromothymol blue (ATV-BTB) chromogen having $\lambda_{\max }$ at $419.4 \mathrm{~nm}$

\begin{tabular}{|c|c|c|}
\hline \multicolumn{3}{|c|}{$\begin{array}{c}\text { TABLE-1 } \\
\text { OPTICAL CHARACTERISTICS OF METHOD A AND B }\end{array}$} \\
\hline Parameters & $\begin{array}{c}\text { Method A } \\
\text { Atazanavir sulfate (ATV) + } \\
\text { Bromophenol blue (BPB) }\end{array}$ & $\begin{array}{c}\text { Method B } \\
\text { Atazanavir sulfate (ATV) + } \\
\text { Bromothymol blue (BTB) }\end{array}$ \\
\hline$\lambda_{\max }(\mathrm{nm})$ & 421.9 & 419.4 \\
\hline Colour & Yellowish & Yellowish Orange \\
\hline Stability (h) & 2 & 3 \\
\hline Beer's law range $(\mu \mathrm{g} / \mathrm{mL})$ & $5-30$ & $10-30$ \\
\hline Limit of detection $(\mu \mathrm{g} / \mathrm{mL})$ & 0.167 & 0.325 \\
\hline Limit of quantification $(\mu \mathrm{g} / \mathrm{mL})$ & 0.506 & 0.984 \\
\hline Molar absorptivity $\left(1 \mathrm{~mol}^{-1} \mathrm{~cm}^{-1}\right)$ & $4.67 \times 10^{3}$ & $2.24 \times 10^{3}$ \\
\hline Sandell's sensitivity $\left(\mu \mathrm{g} \mathrm{cm}^{-2}\right)$ & 0.058 & 0.096 \\
\hline \multicolumn{3}{|c|}{ Regression equation $[\mathrm{Y}=\mathrm{mX}+\mathrm{c}]$} \\
\hline Slope (m) & 0.001 & 0.021 \\
\hline Intercept (c) & 0.0846 & 0.089 \\
\hline Correlation coefficient (r) & 0.999 & 0.998 \\
\hline
\end{tabular}


Optimization of reagent concentration: Optimization of reagents in terms of volume and concentration are very essential to develop a spectrophotometric method. For method A, concentration and volume of bromophenol blue were optimized by taking concentration of 0.05-0.2\% of bromophenol blue and volume of $0.5-2.5 \mathrm{~mL}$. For bromophenol blue $0.1 \%$ concentration of $2 \mathrm{~mL}$ volume of bromophenol blue gave the satisfactory colour. For method B, concentration and volume of bromothymol blue were optimized by taking concentration of $0.05-0.2 \%$ of bromothymol blue and volume of 0.5-2.5 mL. For bromothymol blue $0.1 \%$ concentration of $1 \mathrm{~mL}$ volume of bromothymol blue gave the satisfactory colour.

Assay of formulation: Two different formulations were assayed by the developed methods. The two formulation content were determined and expressed in terms of mean \pm standard deviation and represented in Table-2.

Accuracy and precision: Accuracy of both the methods was done by recovery study by standard addition method. Standard drug was added to pre-analyzed solution of formulations at the level of 25, 50 and $100 \%$. Lower value of standard deviation signifies the accuracy of the methods (Table-3). Precision was evaluated by mean \pm standard deviation of interday and intra-day assay (Table-4).

Limit of detection and limit of quantification: The limit of detection (LOD) and limit of quantification (LOQ) for both the methods with bromophenol blue and bromothymol blue were found to be 0.167 and $0.325 \mu \mathrm{g} / \mathrm{mL}$ and 0.506 and 0.984 $\mu \mathrm{g} / \mathrm{mL}$, respectively.

Specificity and selectivity: Both the methods were done in presence of excipients and changing the reaction conditions slightly. In presence of excipients, no interference was found. The reaction conditions were varied like change of reaction medium, variation in strength and volume of reagents altered the results, which signifies the selectivity of the methods.

Reaction sequence: The sulphonepthalein dyes like bromophenol blue and bromothymol blue exist in lactoid and quinoid tautomeric form. The quinoid form liberates a proton and the anion forms the ion pairing with protonated atazanavir sulfate represented in Scheme-I. Rahman and Azmi ${ }^{31}$, suggested that the quinoid form predominates the lactoid form in strong acidic medium and the opening of lactoid ring is responsible for formation of coloured chromogen with protonated drug. The reaction of atazanavir sulfate with bromophenol blue and bromothymol blue is represented in Schemes I and II respectively. The present method is developed to avoid the complexity of extraction of ion pair complex at a suitable $\mathrm{pH}$. As the method is extraction free and no buffer is used for extraction of ion pair complex, the method is rapid. The ion pair complexes are easily extractable in chloroform, the method is simple. The methods are compared with the previously reported methods ${ }^{28,29}$ and found to be equally significant.

TABLE-2

ASSAY OF ATAZANAVIR SULFATE IN PHARMACEUTICAL FORMULATIONS

\begin{tabular}{cccc}
\hline & & \multicolumn{2}{c}{ Amount of drug found (mg) Mean* \pm S.D } \\
\cline { 3 - 4 } Name of the formulation & Label claim $(\mathrm{mg})$ & $\begin{array}{c}\text { Method A } \\
\text { Method B }\end{array}$ & $\begin{array}{c}\text { (Atazanavir sulfate (ATV) + } \\
\text { Bromothymol blue (BTB) }\end{array}$ \\
\hline Atavir 300 & 300 & $\begin{array}{c}\text { (Atazanavir sulfate (ATV) }+ \\
\text { Bromophenol blue (BPB) }\end{array}$ & $298.08 \pm 0.02$ \\
Atazor 200 & 200 & $299.78 \pm 0.5$ & $200.99 \pm 0.6$ \\
\hline *Mean of five determinations & & $199.63 \pm 0.6$ &
\end{tabular}

TABLE-3

ACCURACY OF THE METHOD (RECOVERY STUDY)

\begin{tabular}{|c|c|c|c|c|c|c|}
\hline \multirow[b]{2}{*}{$\begin{array}{l}\text { Name of the } \\
\text { formulation }\end{array}$} & \multicolumn{3}{|c|}{$\begin{array}{c}\text { Method A [Atazanavir sulfate (ATV) + } \\
\text { Bromophenol blue (BPB)] }\end{array}$} & \multicolumn{3}{|c|}{$\begin{array}{c}\text { Method B [Atazanavir sulfate (ATV) + } \\
\text { Bromothymol blue (BTB)] }\end{array}$} \\
\hline & $\begin{array}{l}\text { Amount of sample } \\
\text { taken }(\mu \mathrm{g} / \mathrm{mL})\end{array}$ & $\begin{array}{c}\text { Amount of } \\
\text { standard taken } \\
(\mu \mathrm{g} / \mathrm{mL})\end{array}$ & $\begin{array}{l}\text { Amount found } \\
(\mu \mathrm{g} / \mathrm{mL}) \\
\text { Mean* } \pm \text { S.D }\end{array}$ & $\begin{array}{l}\text { Amount of sample } \\
\text { taken }(\mu \mathrm{g} / \mathrm{mL})\end{array}$ & $\begin{array}{c}\text { Amount of } \\
\text { standard taken } \\
(\mu \mathrm{g} / \mathrm{mL})\end{array}$ & $\begin{array}{l}\text { Amount found } \\
(\mu \mathrm{g} / \mathrm{mL}) \\
\text { Mean* } \pm \text { S.D }\end{array}$ \\
\hline \multirow{3}{*}{ Atavir 300} & 20 & 5 & $24.94 \pm 0.03$ & 4 & 1 & $5.00 \pm 0.07$ \\
\hline & 20 & 10 & $29.79 \pm 0.03$ & 4 & 2 & $6.04 \pm 0.03$ \\
\hline & 20 & 20 & $39.82 \pm 0.04$ & 4 & 4 & $7.91 \pm 0.04$ \\
\hline \multirow{3}{*}{ Atazor 200} & 20 & 5 & $25.01 \pm 0.03$ & 4 & 1 & $4.96 \pm 0.03$ \\
\hline & 20 & 10 & $30.01 \pm 0.06$ & 4 & 2 & $5.92 \pm 0.03$ \\
\hline & 20 & 20 & $40.00 \pm 0.06$ & 4 & 4 & $7.99 \pm 0.04$ \\
\hline
\end{tabular}

*Mean of five determinations

TABLE-4

\begin{tabular}{|c|c|c|c|c|}
\hline \multicolumn{5}{|c|}{$\begin{array}{c}\text { TABLE-4 } \\
\text { PRECISION OF THE METHODS }\end{array}$} \\
\hline \multirow[b]{2}{*}{ Name of the formulation } & \multicolumn{2}{|c|}{ Intra-day precision $(\mathrm{n}=5)$ Mean* $(\mathrm{mg}) \pm$ S.D } & \multicolumn{2}{|c|}{ Inter-day precision $(\mathrm{n}=3)$ Mean* $(\mathrm{mg}) \pm$ S.D } \\
\hline & $\begin{array}{c}\text { Method A } \\
\text { Atazanavir sulfate (ATV) } \\
\text { + Bromophenol blue } \\
\text { (BPB) }\end{array}$ & $\begin{array}{c}\text { Method B } \\
\text { Atazanavir sulfate (ATV) } \\
+ \text { Bromothymol blue } \\
\text { (BTB) }\end{array}$ & $\begin{array}{c}\text { Method A } \\
\text { Atazanavir sulfate (ATV) } \\
+ \text { Bromophenol blue } \\
(\mathrm{BPB})\end{array}$ & $\begin{array}{c}\text { Method B } \\
\text { Atazanavir sulfate (ATV) } \\
+ \text { Bromothymol blue } \\
\text { (BTB) }\end{array}$ \\
\hline Atavir 300 & $299.95 \pm 0.6$ & $300.16 \pm 0.26$ & $299.83 \pm 0.15$ & $299.17 \pm 0.03$ \\
\hline Atazor 200 & $200.9 \pm 0.15$ & $200.04 \pm 0.26$ & $200.06 \pm 0.06$ & $200.12 \pm 0.04$ \\
\hline
\end{tabular}


<smiles>O=C(O)Oc1ccccc1C1(c2cc(Br)c(O)c(Br)c2Br)c2ccccc2Oc2c1cc(Br)c(O)c2Br</smiles>

Lactone ring<smiles>O=c1c(Br)cc2c(-c3ccccc3O)c3cc(Br)c(O)c(Br)c3oc-2c1Br</smiles>

Quinoid ring<smiles>O=c1c(Br)cc2c(-c3ccccc3[O+])c3cc(Br)c(O)c(Br)c3oc-2c1Br</smiles>

Bromophenol blue

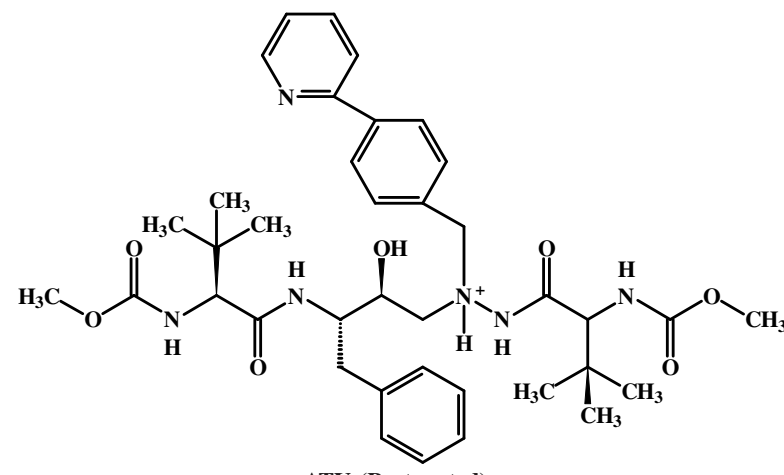

ATV (Protonated)<smiles>O=c1c(Br)cc2c(-c3ccccc3[O+])c3cc(Br)c(O)c(Br)c3oc-2c1Br</smiles>

Bromophenol blue<smiles>[H][Y](Cc1ccc(-c2ccccn2)cc1)(CC(O)[C@@H](Cc1ccccc1)NC(=O)C(NC(=O)OC)C(C)(C)C)NC(=O)C(NC(=O)OC)C(C)(C)C</smiles>

ATV-Bromophenol blue complex

Scheme-I

Statistical analysis: Two way ANOVA was applied to test both method-sample interaction and differences in method precision. In both the cases F stat $<$ F crit, signifying the method -sample interaction and the differences between the methods are not significant (Table-5).

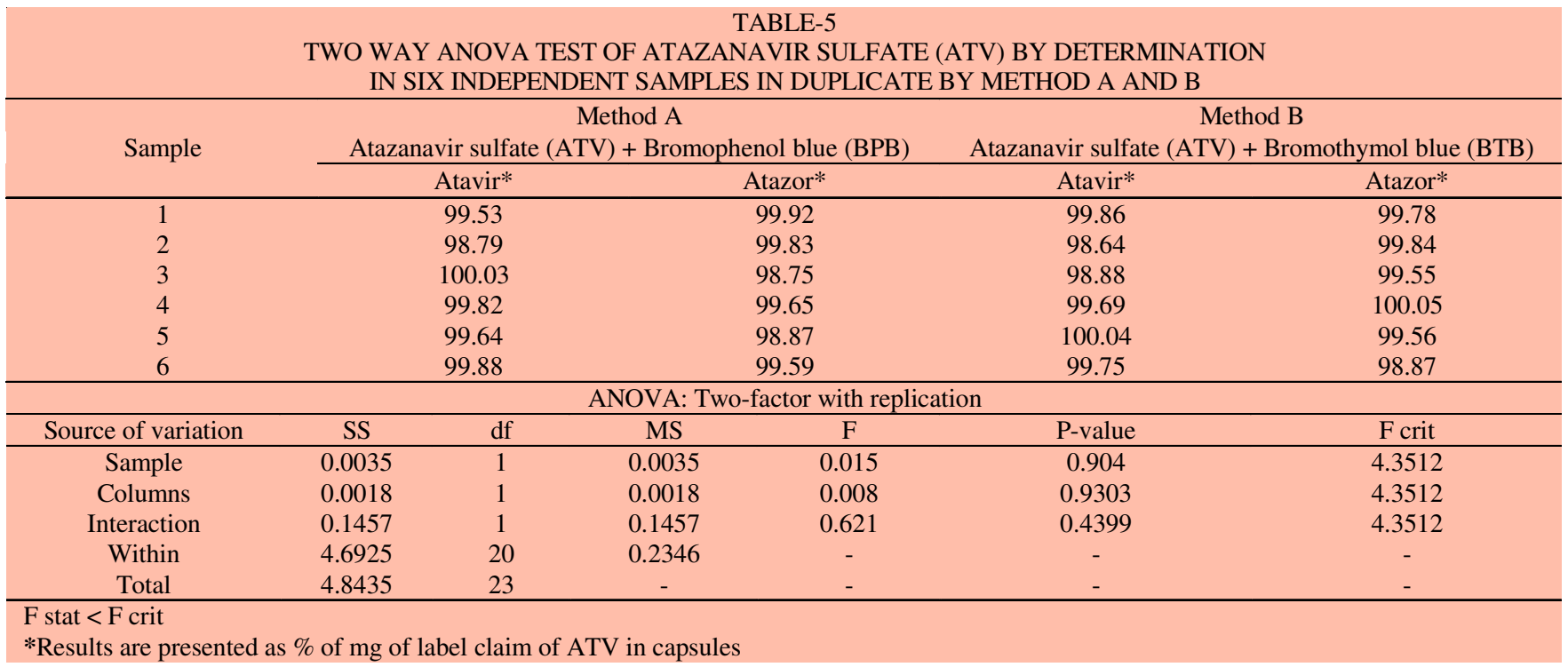




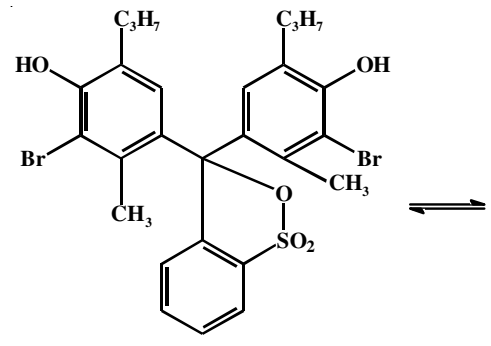

Lactone ring

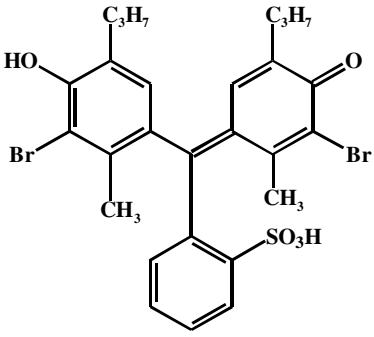

Quinoid ring

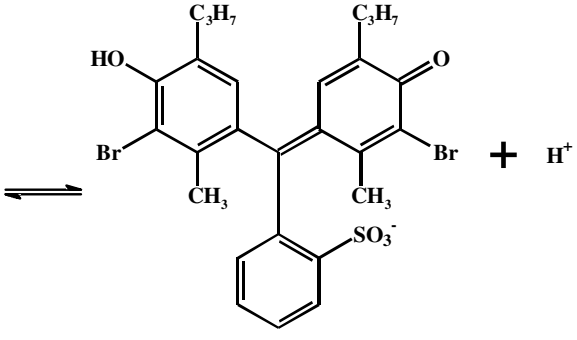

Bromophenol blue<smiles>COC(=O)NC(C(=O)NC(Cc1ccccc1)C(O)CN([Tl])Cc1ccc(-c2ccccn2)cc1)C(C)(C)C</smiles>

ATV (Protonated) $\mathrm{H}_{3} \mathrm{C}{\underset{\mathrm{CH}}{3}}_{\mathrm{CH}_{3}}$

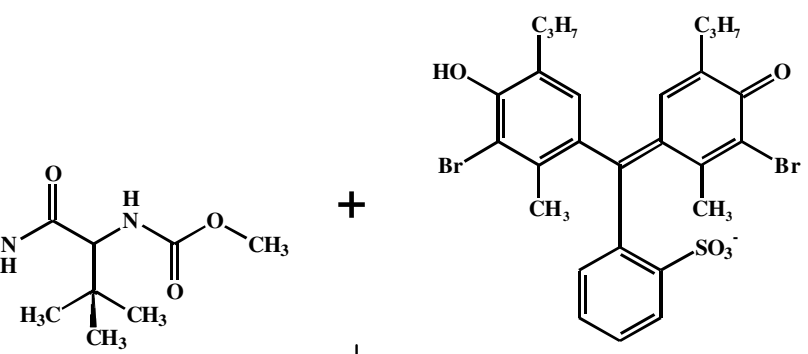

Bromothymol blue<smiles>CC[C@H](O)C(Cc1ccccc1)NC(=O)C(NC(=O)OC)C(C)(C)C</smiles><smiles>CNC(=O)C(NC(=O)OC)C(C)(C)C</smiles><smiles></smiles>

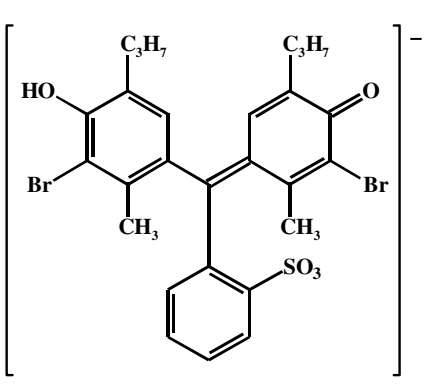

ATV-Bromothymol blue complex

Scheme-II

TABLE-6

AVERAGE RESULTS OF ATAVIR (a) AND ATAZOR (b) DETERMINATION BY METHOD A AND B AND THEIR CORRELATION BY PAIRED $t$-test

\begin{tabular}{|c|c|c|}
\hline Sample & Method $\mathrm{A}^{\#}$ & Method B \\
\hline \multicolumn{3}{|c|}{ (a) Atavir } \\
\hline 1 & 99.53 & 99.86 \\
\hline 2 & 98.79 & 98.64 \\
\hline 3 & 100.03 & 98.88 \\
\hline 4 & 99.82 & 99.69 \\
\hline 5 & 99.64 & 100.04 \\
\hline 6 & 99.88 & 99.75 \\
\hline Average & 99.615 & 99.476 \\
\hline \multicolumn{3}{|c|}{$t$-test: Paired two sample for means } \\
\hline & Variable 1 & Variable 2 \\
\hline Mean & 99.615 & 99.4766 \\
\hline Variance & 0.1945 & 0.3281 \\
\hline Observations & 6 & 6 \\
\hline Pearson Correlation & 0.4276 & \\
\hline Hypothesized Mean Difference & 0 & \\
\hline df & 5 & \\
\hline$t$ Stat & 0.612 & \\
\hline $\mathrm{P}(\mathrm{T}<=\mathrm{t})$ one-tail & 0.2836 & \\
\hline$t$ Critical one-tail & 2.015 & \\
\hline $\mathrm{P}(\mathrm{T}<=\mathrm{t})$ two-tail & 0.5673 & \\
\hline$t$ Critical two-tail & 2.5705 & \\
\hline$t$ Stat $<t$ critical & & \\
\hline
\end{tabular}

\begin{tabular}{|c|c|c|}
\hline Sample & Method A* & Method B* \\
\hline \multicolumn{3}{|c|}{ (b) Atazor } \\
\hline 1 & 99.92 & 99.78 \\
\hline 2 & 99.83 & 99.84 \\
\hline 3 & 98.75 & 99.55 \\
\hline 4 & 99.65 & 100.05 \\
\hline 5 & 98.87 & 99.56 \\
\hline 6 & 99.59 & 98.87 \\
\hline Average & 99.435 & 99.60 \\
\hline \multicolumn{3}{|c|}{$t$-test: Paired two sample for means } \\
\hline & Variable 1 & Variable 2 \\
\hline Mean & 99.435 & 99.608 \\
\hline Variance & 0.25 & 0.166 \\
\hline Observations & 6 & 6 \\
\hline Pearson Correlation & 0.219 & - \\
\hline Hypothesized Mean Difference & 0 & - \\
\hline $\mathrm{df}$ & 5 & - \\
\hline$t$ Stat & -0.742 & - \\
\hline $\mathrm{P}(\mathrm{T}<=\mathrm{t})$ one-tail & 0.245 & - \\
\hline$t$ Critical one-tail & 2.015 & - \\
\hline $\mathrm{P}(\mathrm{T}<=\mathrm{t})$ two-tail & 0.491 & - \\
\hline$t$ Critical two-tail & 2.57 & - \\
\hline$t$ Stat $<t$ critical & - & - \\
\hline
\end{tabular}


To test means a paired student's $t$-test was applied. The test removes any variation between samples. From the student's $t$-test, $t$ stat $<t$ crit was found in both the cases signifying there is no significant difference between the means (Table-6).

\section{Conclusion}

The developed methods were validated and found to be simple, accurate and precise. The developed methods are equally significant with the reported methods. The instrument and the chemicals used in the developed methods are easily available in any small laboratories, so these methods can be used for both qualitative and quantitative estimation of atazanavir sulfate in bulk and dosage form.

\section{ACKNOWLEDGEMENTS}

The authors are thankful to Siksha 'O' Anusandhan University for providing the research facilities to carry out the research work.

\section{REFERENCES}

1. K. Fukushima, S. Terasaka, K. Haraya, S. Kodera, Y. Seki, A. Wada, Y. Ito, N. Shibata, N. Sugioka and K. Takada, Biol. Pharm. Bull., 30, 733 (2007)

2. The Indian Pharmacopoeia, Indian Pharmacopoeia Commission: Ghaziabad, India, Vol. 2, p. 844 (2010).

3. E.S. Perloff, S.X. Duan, P.R. Skolnik, D.J. Greenblatt and L.L. von Moltke, Drug Metab. Dispos., 33, 764 (2005).

4. R. ter Heine, M. Davids, H. Rosing, E.C.M. van Gorp, J.W. Mulder, Y.T. van der Heide, J.H. Beijnen and A.D.R. Huitema, J. Chromatogr. B, 877, 575 (2009).

5. R. ter Heine, H. Rosing, E.C.M. van Gorp, J.W. Mulder, W.A. van der Steeg, J.H. Beijnen and A.D.R. Huitema, J. Chromatogr. B, 867, 205 (2008).

6. A. D'Avolio, M. Siccardi, M. Sciandra, B. Lorena, S. Bonora, L. Trentini and G. Di Perri, J. Chromatogr. B, 859, 234 (2007).

7. R. ter Heine, C.G. Alderden Los, H. Rosing, M.J.X. Hillebrand, E.C.M van Gorp, A.D.R. Huitema and J.H. Beijnen, Rapid Commun. Mass Spectrom., 21, 2505 (2007).

8. L. Dickinson, L. Robinson, J. Tjia, S. Khoo and D. Back, J. Chromatogr. $B, 829,82$ (2005).

9. T. Koal, H. Burhenne, R. Römling, M. Svoboda, K. Resch and V. Kaever, Rapid Commun. Mass Spectrom., 19, 2995 (2005).
10. S. Colombo, A. Beguin, A. Telenti, J. Biollaz, T. Buclin, B. Rochat and L.A. Decosterd, J. Chromatogr. B, 819, 259 (2005).

11. K.M.L. Crommentuyn, H. Rosing, M.J.X. Hillebrand, A.D.R. Huitema and J.H. Beijnen, J. Chromatogr. B, 804, 359 (2004).

12. M. Jemal, S. Rao, M. Gatz and D. Whigan, J. Chromatogr. B, 795, 273 (2003).

13. A. Schuster, S. Burzawa, M. Jemal, E. Loizillon, P. Couerbe and D. Whigan, J. Chromatogr. B, 788, 377 (2003).

14. D. Cattaneo, F. Maggiolo, D. Ripamonti and N. Perico, J. Chromatogr. Sci., 46, 485 (2008)

15. U. Seshachalam, D.V.L.N. Rao, B. Haribabu and K.B. Chandrasekhar, Chromatographia, 65, 355 (2007).

16. K. Keil, J. Hochreitter, R. DiFrancesco, B.S. Zingman, R.C. Reichman, M.A. Fischl, B. Gripshover and G.D. Morse, Ther. Drug Monit., 29, 103 (2007).

17. R. Verbesselt, E. van Wijngaerden and J. de Hoon, J. Chromatogr. B, 845, 51 (2007).

18. A. Loregian, S. Pagni, E. Ballarin, E. Sinigalia, S.G. Parisi and G. Palu, J. Pharm. Biomed. Anal., 42, 500 (2006).

19. N.L. Rezk, R.D. Crutchley, R.F. Yeh and A.D.M. Kashuba, Ther. Drug Monit., 28, 517 (2006)

20. R.W. Sparidans, F. Dost, K.M.L. Crommentuyn, A.D.R. Huitema, J.H.M. Schellens and J.H. Beijnen, Biomed. Chromatogr., 20, 72 (2006).

21. E. Cateau, N. Tournier, A. Dupuis, G.L. Moal and N. Venisse, J. Pharm. Biomed. Anal., 39, 791 (2005).

22. O. Tribut, M.C. Verdier, C. Arvieux, H. Allain, C. Michelet and D. Bentue-Ferrer, Ther. Drug Monit., 27, 265 (2005).

23. J.M. Poirier, P. Robidou and P. Jaillon, Ther. Drug Monit., 27, 186 (2005).

24. E. Dailly, F. Raffi and P. Jolliet, J. Chromatogr. B, 813, 353 (2004).

25. S. Colombo, N. Guignard, C. Marzolini, A. Telenti, J. Biollaz and L.A. Decosterd, J. Chromatogr. B, 810, 25 (2004).

26. S.R. Chitturi, Y.S. Somannavar, B.G. Peruri, S. Nallapati, H.K. Sharma, S.R. Budidet, V.K. Handa and H.B. Vurimindi, J. Pharm. Biomed. Anal., 55, 31 (2011).

27. S. Dey, Y.V. Reddy, T. Reddy, S.K. Sahoo, P.N. Murthy, S. Mohapatra and S.S. Patro, Int. J. Pharm. Bio. Sci., 1, 1 (2010).

28. A. Behera, S.K. Moitra, S.C. Si and D.G. Sankar, Quim. Nova, 34, 1349 (2011)

29. A. Behera, D.G. Sankar, S.K. Moitra and S.C. Si, E.-J. Chem., 9, 1778 (2012).

30. ICH Guideline, Q2(R1): Validation of Analytical Procedures: Text and Methodology, International Conference on Harmonization, Geneva (2005).

31. N. Rahman and S.N. Hejaz-Azmi, J. Pharm. Biomed. Anal., 24, 33 (2000). 